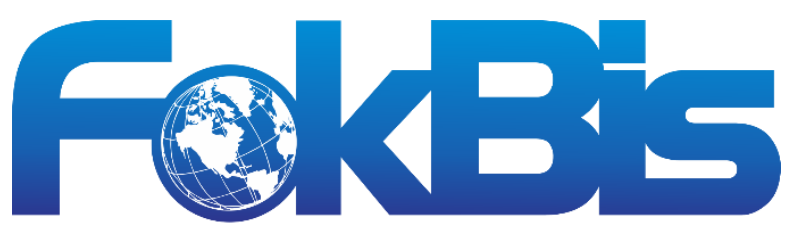

Media Pengkajian Manajemen dan Akuntansi

http://journal.stieputrabangsa.ac.id/index.php/fokbis/index

ISSN: 2623-2480/ P-ISSN: 1693-5209

\section{ANALISIS GAME THEORY PADA STRATEGI BERSAING GRAB DAN GO-JEK DI KABUPATEN KEBUMEN}

\author{
Wahyuni Windasari ${ }^{1}$, Tuti Zakiyah ${ }^{2}$ \\ ${ }^{1,2)}$ STIE Putra Bangsa, Kebumen, Indonesia \\ email: wahyuwindasari@gmail.com
}

\section{Article Information}

\section{History of Article:}

Received September $8^{\text {th }}, 2019$

Accepted October 30th 2019

Published December 23rd, 2019

\section{DOI:}

10.32639/fokusbisnis.v\%vi\%i.329

\begin{abstract}
The phenomenon of online transportation in Kebumen has resulted in competition between Grab and Gojek service providers. Intense market competition requires that both companies know the best strategies that can be used. This study aims to obtain an optimal marketing strategy based on consumer ratings using eight marketing attributes, namely practical, cost-effective, safety, comfort, promos, fleet availability, non-cash payments, and completeness of facilities. Data processing uses game theory with Grab as the dominant company. The results of this research show that the optimal strategy for Grab to increase profits is the convenience strategy and voucher promo, while for Gojek the strategy used to minimize losses is security and cost tariffs.
\end{abstract}

Keywords: Marketing Strategy, Optimal Strategy, Game Theory

\title{
PENDAHULUAN
}

Jasa transportasi saat ini menjadi kebutuhan utama masyarakat. Transportasi memiliki fungsi yang strategis karena keberlangsungan dan kelancaran kegiatan masyarakat sangat tergantung pada akses transportasi. Kecepatan dan kemudahan dalam mengakses alat transportasi merupakan hal penting yang menjadi pertimbangan masyarakat dalam memilih jasa transportasi. Melihat kebutuhan akan transportasi yang semakin meningkat, maka bisnis di bidang transportasipun semakin berkembang. Salah satu bukti nyatanya adalah hadirnya transportasi inovatif berupa ojek online di Indonesia. Fenomena ojek online di Indonesia memberikan solusi akan kekhawatiran masyarakat tentang kemacetan yang sering terjadi di kota-kota besar dan tentang jaminan keamanan penumpang yang menggunakan armada transportasi umum atau konvensional. Ojek online banyak diminati oleh masyarakat diantaranya memiliki kelebihan 
yaitu aplikasi berbasis data, dimana masyarakat dapat mengetahui identitas pengemudi kendaraan bermotor. Dengan kelebihan ini, masyarakat bisa mendapatkan informasi siapakah yang akan menjadi pengemudi layanan transportasi yang telah dipesan, lengkap dengan data diri pengemudi atau driver yang bersangkutan (Anindhita, 2017). Layanan ojek online hanya bisa diperoleh dengan pemesanan via aplikasi transportasi online seperti Go-jek, Uber dan Grab (Kurnianti, 2017).

Awalnya, transportasi online hanya bisa dinikmati di kota besar seperti Jakarta, Yogyakarta atau Bandung. Kini, transportasi online mulai tersebar ke berbagai kota di wilayah lain, salah satunya adalah kabupaten Kebumen. Transportasi online dinilai sebagai salah satu indikator berkembangnya moda transportasi publik yang ada dalam sebuah kota. Adanya transportasi online dapat menjadi jawaban atas prinsip aksesibilitas transportasi. Sebelumnya masyarakat apabila akan bepergian hanya dapat mengandalkan moda transportasi umum seperti kereta, bus angkutan kota, maupun bus umum yang memakan waktu tunggu yang cukup lama tetapi dengan kemunculan transportasi online masyarakat dapat fleksibel dan dapat memesan sendiri moda transportasi yang dikehendaki tanpa harus menunggu lama. Transportasi online yang tersedia di kabupaten Kebumen adalah Go-Jek dan Grab. Kesamaan dalam hal pemenuhan kebutuhan pelanggan di bidang transportasi membuat Go-Jek dan Grab bersaing satu sama sama lain. Sehingga diperlukan antisipasi kemungkinan strategi yang akan diterapkan oleh lawan/ pesaing Go-Jek dan Grab melakukan aktivitas pemasaran dengan berupaya menciptakan keunggulan dari berbagai faktor yang dapat menarik pelanggan untuk menggunakan jasanya. Penentuan strategi pemasaran harus didasarkan atas analisa lingkungan baik eksternal maupun intenal pemasar.

Menurut Anggraini (2017), faktor eksternal dapat menimbulkan kesempatan bahkan ancaman bagi pemasaran produk suatu perusahaan, yaitu keadaan pasar, persaingan, teknologi, ekonomi, sosial budaya, hukum dan peraturan. Sedangkan faktor-faktor internal menunjukkan adanya keunggulan atau kelemahan perusahaan, meliputi keuangan, produksi, personalia dan pemasaran. Khusus di bidang pemasaran jasa, bauran pemasaran jasa menjadi dasar strategi yang dilakukan oleh setiap perusahaan, yang terdiri atas produk, harga, promosi, lokasi, proses, personel dan bukti fisik.

Kotler dan Keller (2009:6) menyatakan manajemen pemasaran sebagai seni dan ilmu memilih pasar sasaran dan mendapatkan, menjaga, dan menumbuhkan pelanggan dengan menciptakan, menyerahkan dan mengkomunikasikan nilai pelanggan yang unggul. Salah satu cara yang dapat digunakan untuk menganalisa strategi pemasaran adalah dengan menggunakan teori permainan (game theory). Untuk memperkirakan strategi pemasaran terbaik yang harus dilakukan, maka perusahaan harus mempelajari atau paling tidak memperkirakan langkah- langkah pihak pesaingnya. Penelitian ini bertujuan untuk menganalisis strategi optimal dalam persaingan antara Go-Jek dan Grab di Kabupaten Kebumen.

Game theory dikembangkan untuk menganalisa proses pengambilan keputusan dari situasi persaingan yang berbeda-beda dan melibatkan dua atau lebih kepentingan. Kepentingan-kepentingan yang bersaing dalam permainan disebut sebagai pemain. Anggapannya adalah bahwa setiap pemain mempunyai kemampuan untuk mengambil keputusan secara secara bebas dan rasional (Subagyo, 2009).

\section{METODE}

Penelitian ini merupakan penelitian kuantitatif dengan metode pengumpulan data menggunakan metode kuisioner. Adapun responden dalam penelitian ini adalah pengguna kedua transportasi Grab dan Go-Jek di Kabupaten Kebumen. Oleh karena jumlah populasi tidak diketahui maka metode pengumpulan sampel dilakukan dengan rumus sebagai berikut:

$$
n=\frac{Z^{2}}{4(m o e)^{2}}
$$


Keterangan :

$$
\begin{gathered}
n=\frac{1,96^{2}}{4(0,1)^{2}} \\
n=96,04
\end{gathered}
$$

n : Jumlah sampel

Z : : Z score pada tingkat signifikansi tertentu (diambil tingkat kepercayaan 95\%)

Moe : Margin of error, dengan tingkat kesalahan maksimum $10 \%$

Menurut hasil perhitungan, sampel yang dapat diambil adalah 97 orang, akan tetapi pada prinsipnya tidak ada aturan yang pasti untuk menentukan presentase yang dianggap tetap dalam menetukan sampel. Maka dalam hal ini peneliti mengambil sebanyak 100 orang responden yang cukup mewakili untuk diteliti.

Analisis data penelitian dilakukan dengan analisis game theory dengan menggunakan bantuan software QM for windows. Adapun langkah-langkah analisis data sebagai berikut :

1. Menentukan strategi pemasaran yang digunakan oleh perusahaan transportasi online. Menurut Tri Paulina (2018), penentuan strategi pemasaran dalam game theory didasarkan pada penilaian tingkat kepentingan dari konsumen. Dalam penelitiannya terdapat enam hal yang digunakan yaitu praktis, hemat, aman, promosi, armada lebih banyak, dan pembayaran non tunai. Selanjutnya, dalam penelitian kali ini ditambahkan variabel kenyamanan dan kelengkapan fasilitas sebagai variabel yang juga tak kalah dipentingkan oleh konsumen.

Tabel 1. Variabel dalam Game Theory

\begin{tabular}{lcc}
\hline Atribut pada Permainan & \multicolumn{2}{c}{$\begin{array}{c}\text { Variabel yang } \\
\text { Digunakan }\end{array}$} \\
\cline { 2 - 3 } & Grab & Gojek \\
\hline Praktis & $X_{1}$ & $Y_{1}$ \\
Hemat Biaya & $X_{2}$ & $Y_{2}$ \\
Keamanan & $X_{3}$ & $Y_{3}$ \\
Kenyamanan & $X_{4}$ & $Y_{4}$ \\
Promo (voucher) & $X_{5}$ & $Y_{5}$ \\
Ketersediaan Armada & $X_{6}$ & $Y_{6}$ \\
Pembayaran Non-Tunai & $X_{7}$ & $Y_{7}$ \\
Kelengkapan Fasilitas & $X_{8}$ & $Y_{8}$ \\
\hline
\end{tabular}

sumber: data diolah, 2019

2. Mengumpulkan data primer dengan penyebaran kuesioner untuk mengetahui persepsi pengguna transportasi online mengenai keunggulan masing-masing perusahaan transportasi online, dalam hal ini adalah Grab dan Go-Jek 
3. Mengolah data dengan teori permainan

a. Menentukan pemain baris dan pemain kolom. Pemain baris adalah pemain yang dianggap memiliki keuntungan, sedangkan pemain kolom adalah pemain yang dianggap menderita kerugian.

b. Menentukan nilai maksimin dan minimaks. Maximin adalah nilai maksimum dari nilai- nilai perolehan yang minimum, sedangkan Minimax adalah nilai minimum dari nilai- nilai perolehan yang maksimum

c. Menghitung saddle point untuk menentukan apakah strategi yang digunakan adalah strategi murni, atau strategi campuran

d. Menarik kesimpulan.

\section{HASIL DAN PEMBAHASAN}

Pada bagian ini dibahas tentang uji validitas, reliabilitas, dan pengolahan data menggunakan $Q M$ for windows.

\section{Uji Validitas}

Pengujian validitas data dalam penelitian ini menggunakan SPSS 22 dengan $n=100$, derajat kebebasan $(\mathrm{df})=\mathrm{n}-2=98$ dan tingkat signifikansi $5 \%$ maka diperoleh $r_{\text {tabel }}=0.197$. Adapun hasil validitas data kuisioner secara lengkap diberikan pada Tabel 2 berikut ini :

Tabel 2. Hasil Uji Validitas Data Kuisioner

\begin{tabular}{cccc}
\hline No. & Atribut & $\boldsymbol{r}_{\text {hitung }}$ & Keterangan \\
\hline 1 & Praktis & 0.699 & Valid \\
2 & Hemat Biaya & 0.769 & Valid \\
3 & Keamanan & 0.714 & Valid \\
4 & Kenyamanan & 0.641 & Valid \\
5 & Promo (voucher) & 0.577 & Valid \\
6 & Ketersediaan Armada & 0.689 & Valid \\
7 & Pembayaran Non-Tunai & 0.655 & Valid \\
8 & Kelengkapan Fasilitas & 0.597 & Valid \\
\hline
\end{tabular}

sumber: data diolah, 2019

\section{Uji Reliabilitas}

Dari hasil uji reliabilitas dengan bantuan software SPSS diperoleh nilai $\alpha=0.817>0.60$, yang artinya setiap strategi yang digunakan pada kuisioner dinyatakan reliabel.

\section{Pengolahan Data Game Theory}

Data pada penelitian ini diperoleh dari hasil kuisioner yang berisi tentang perbandingan setiap atribut variabel yang ada. Nilai perbandingan diperoleh dari selisih total nilai dari responden yang lebih mementingkan Grab daripada Go-Jek di setiap variabel atribut yang diberikan. Adapun hasil perbandingan diberikan pada Tabel 3.

\section{Tabel 3. Matriks Nilai Perolehan Grab dan Gojek}




\begin{tabular}{l|llllllll}
\hline & $\boldsymbol{Y}_{\mathbf{1}}$ & $\boldsymbol{Y}_{\mathbf{2}}$ & $\boldsymbol{Y}_{\mathbf{3}}$ & $\boldsymbol{Y}_{\mathbf{4}}$ & $\boldsymbol{Y}_{\mathbf{5}}$ & $\boldsymbol{Y}_{\mathbf{6}}$ & $\boldsymbol{Y}_{\mathbf{7}}$ & $\boldsymbol{Y}_{\mathbf{8}}$ \\
\hline $\boldsymbol{X}_{\mathbf{1}}$ & 48 & 18 & 14 & 28 & 22 & 34 & 54 & 34 \\
$\boldsymbol{X}_{\mathbf{2}}$ & 62 & 36 & 32 & 52 & 44 & 54 & 58 & 54 \\
$\boldsymbol{X}_{\mathbf{3}}$ & 44 & 28 & 34 & 36 & 52 & 54 & 52 & 46 \\
$\boldsymbol{X}_{\mathbf{4}}$ & 58 & 26 & 36 & 46 & 42 & 48 & 68 & 42 \\
$\boldsymbol{X}_{\mathbf{5}}$ & 62 & 42 & 32 & 36 & 38 & 52 & 58 & 48 \\
$\boldsymbol{X}_{\mathbf{6}}$ & 52 & 24 & 30 & 50 & 32 & 58 & 56 & 26 \\
$\boldsymbol{X}_{\mathbf{7}}$ & 56 & 30 & 32 & 34 & 34 & 36 & 30 & 14 \\
$\boldsymbol{X}_{\mathbf{8}}$ & 60 & 46 & 30 & 38 & 30 & 48 & 56 & 36 \\
\hline
\end{tabular}

sumber: data diolah, 2019

Dari hasil matriks perolehan selanjutnya dilakukan penghitungan maksimin untuk pemain baris dan minimin untuk pemain kolom untuk menentukan strategi yang akan digunakan

Tabel 4. Hasil Nilai Teori Permainan untuk Strategi Murni

\begin{tabular}{c|ccccccccc}
\hline & $\boldsymbol{Y}_{\mathbf{1}}$ & $\boldsymbol{Y}_{\mathbf{2}}$ & $\boldsymbol{Y}_{\mathbf{3}}$ & $\boldsymbol{Y}_{\mathbf{4}}$ & $\boldsymbol{Y}_{\mathbf{5}}$ & $\boldsymbol{Y}_{\mathbf{6}}$ & $\boldsymbol{Y}_{\mathbf{7}}$ & $\boldsymbol{Y}_{\mathbf{8}}$ & $\mathbf{M i n}$ \\
\hline $\boldsymbol{X}_{\mathbf{1}}$ & 48 & 18 & 14 & 28 & 22 & 34 & 54 & 34 & 14 \\
$\boldsymbol{X}_{\mathbf{2}}$ & 62 & 36 & 32 & 52 & 44 & 54 & 58 & 54 & $\mathbf{3 2}$ \\
& & & & & & & & & 28 \\
$\boldsymbol{X}_{\mathbf{3}}$ & 44 & 28 & 34 & 36 & 52 & 54 & 52 & 46 & 26 \\
$\boldsymbol{X}_{\mathbf{4}}$ & 58 & 26 & 36 & 46 & 42 & 48 & 68 & 42 & 32 \\
$\boldsymbol{X}_{\mathbf{5}}$ & 62 & 42 & 32 & 36 & 38 & 52 & 58 & 48 & 24 \\
$\boldsymbol{X}_{\mathbf{6}}$ & 52 & 24 & 30 & 50 & 32 & 58 & 56 & 26 & 14 \\
$\boldsymbol{X}_{\mathbf{7}}$ & 56 & 30 & 32 & 34 & 34 & 36 & 30 & 14 & 30 \\
$\boldsymbol{X}_{\mathbf{8}}$ & 60 & 46 & 30 & 38 & 30 & 48 & 56 & 36 & 54 \\
$\mathbf{M a x}$ & 62 & 46 & 36 & 52 & 52 & 58 & 68 & 54 & \\
\hline
\end{tabular}

sumber: data diolah, 2019

Dari Tabel 4 terlihat bahwa nilai maksimin yaitu 32 tidak sama dengan nilai minimaksnya yaitu 36 artinya permainan tidak bisa diselesaikan dengan menggunakan strategi murni. Langkah selanjutnya dilakukan analisis menggunakan strategi dominasi. Strategi dominasi ini diterapkan dengan cara mengeluarkan baris yang didominasi untuk pemain baris dan sebaliknya untuk pemain kolom, kolom yang dikeluarkan adalah kolom yang mendominasi. Dari tabel 4 , dilakukan proses iterasi pengurangan baris yang didominasi secara berturut-turut yaitu baris $X_{1}, X_{2}, X_{3}, X_{6}, X_{7}$ dan kolom yang mendominasi secara berturut-turut yaitu kolom $Y_{1}, Y_{4}, Y_{5}, Y_{6}, Y_{7}, Y_{8}$ sehingga diperoleh matriks berukuran $\mathrm{M} \times 2$ sebagai berikut:

Tabel 5. Matrik Pay Off Tereduksi

\begin{tabular}{c|rr}
\hline & $\boldsymbol{Y}_{\mathbf{2}}$ & $\boldsymbol{Y}_{\mathbf{3}}$ \\
\hline $\boldsymbol{X}_{\mathbf{4}}$ & 26 & 36 \\
$\boldsymbol{X}_{\mathbf{5}}$ & 42 & 32 \\
$\boldsymbol{X}_{\mathbf{8}}$ & 46 & 30 \\
\hline
\end{tabular}

sumber: data diolah, 2019 
Dari matrik pay off tereduksi diperoleh tiga variasi untuk menentukkan game value yang digunakan.

Tabel 6. Variasi 1

\begin{tabular}{c|cc}
\hline & $Y_{2}$ & $Y_{3}$ \\
\hline$X_{4}$ & 26 & 36 \\
$X_{5}$ & 42 & 32 \\
\hline \multicolumn{3}{c}{ sumber: data diolah, 2019}
\end{tabular}

Tabel variasi 1 diketahui nilai minimaks $\neq$ maksimin sehingga tidak dapat digunakan strategi murni. Selanjutnya untuk mengembangkan pola strategi campuran digunakan metode analisis untuk menentukan nilai probabilitas untuk strategi yang berbeda. Dengan menggunakan metode analisis diperoleh nilai probabilitas strategi untuk Grab adalah strategi $X_{4}$ dan $X_{5}$ masing-masing sebesar $50 \%$, dengan perolehan nilai keuntungan sebesar 34. Sedangkan untuk Gojek, probabilitas untuk strategi $Y_{2}$ sebesar $20 \%$ sedangkan strategi $Y_{3}$ sebesar $80 \%$. Dengan demikian diperoleh nilai kerugian minimum bagi Gojek adalah sebesar 34

Tabel 7. Variasi 2

\begin{tabular}{l|cc}
\hline & $\boldsymbol{Y}_{\mathbf{2}}$ & $\boldsymbol{Y}_{\mathbf{3}}$ \\
\hline $\boldsymbol{X}_{\mathbf{4}}$ & 26 & 36 \\
$\boldsymbol{X}_{\mathbf{8}}$ & 46 & 30 \\
\hline \multicolumn{3}{l}{ sumber: data diolah, 2019}
\end{tabular}

Tabel variasi 2 diketahui nilai minimaks $\neq$ maksimin sehingga tidak dapat digunakan strategi murni. Selanjutnya untuk mengembangkan pola strategi campuran digunakan metode analisis untuk menentukan nilai probabilitas untuk strategi yang berbeda. Dengan menggunakan metode analisis diperoleh nilai probabilitas strategi untuk Grab adalah strategi $X_{4}$ sebesar $61.54 \%$ dan $X_{8}$ sebesar 38.46 $\%$, dengan perolehan nilai keuntungan sebesar 33.69. Sedangkan untuk Gojek, probabilitas untuk strategi $Y_{2}$ sebesar $23.08 \%$ sedangkan strategi $Y_{3}$ sebesar $76.92 \%$. Dengan demikian diperoleh nilai kerugian minimum bagi Gojek adalah sebesar 33.69.

Tabel 8. Variasi 3

\begin{tabular}{c|cc}
\hline & $Y_{2}$ & $Y_{3}$ \\
\hline$X_{5}$ & 42 & 32 \\
$X_{8}$ & 46 & 30 \\
\hline
\end{tabular}

sumber: data diolah, 2019

Tabel variasi 3 diketahui nilai minimaks sudah sama dengan nilai maksimin sehingga sadle point sudah tercapai. Dengan menggunakan strategi murni diperoleh nilai keuntungan maksimal bagi Grab dan kerugian minimum bagi Gojek adalah sebesar 32.

Dari ketiga variasi di atas, maka dapat diperoleh hasil yang terbaik diberikan oleh variasi pertama dengan nilai game value sebesar 34. Solusi ini merupakan solusi yang optimal bagi kedua pemain baik Grab maupun Gojek.

\section{SIMPULAN}

Berdasarkan hasil penelitian, dapat disimpulkan bahwa strategi yang optimal bagi perusahaan Grab untuk meningkatkan keuntungan adalah strategi pemasaran yang lebih mengutamakan kenyamanan dan promo voucher, sedangkan strategi yang optimal bagi perusahaan Gojek untuk menurunakn kerugian strategi pemasaran yang lebih mengutamakan pada atribut keamanan dan tarif biaya. Untuk penelitian selanjutnya 
dapat dilakukan pengembangan lebih lanjut dengan menambahkan atribut yang lebih luas dan lebih sesuai dengan perkembangan pemasaran ojek online, misalkan atribut fasilitas sewa kendaraan maupun fasilitas pembayaran pulsa dan token, selain itu penelitian selanjutnya dapt dilakukan dengan pengembangan menggunakan fuzzy game theory

\section{REFERENSI}

Anggraini, Dian, dkk. 2017. Aplikasi Logika Fuzzy Dalam Teori Permainan Untuk Menentukan Strategi Pemasaran (Studi Kasus: Persaingan Alfamart Dan Indomaret). Prosiding Seminar Nasional Matematika dan Pendidikan Matematika. UIN Raden Intan Lampung.

Anindhita, Arisanty dan Devie Rahmawati. 2017. Analisis Penerapan Teknologi Komunikasi Tepat Guna pada Bisnis Transportasi Ojek Online. Prosiding Seminar Nasional INDOCOMPAC : Universitas Bakrie.

Buchari, Alma. 2008. Manajemen Pemasaran dan Pemasaran Jasa. Bandung : Alfabeta.

Kotler dan Keller. 2009. Manajemen Pemasaran. Jilid I. Edisi ke 13. Jakarta : Erlangga.

Kotler, Philip dan Amstrong, Gary. 2012. Prinsip- Prinsip Pemasaran. Jilid I. Edisi ke 13. Jakarta : Erlangga.

Kurnianti, Apsari Wahyu. 2017. Komunikasi Pemasaran Transportasi Online NGuberJEK. Jurnal Komunikasi Dan Kajian Media. Vol 1 No. 1 Hal 69-84.

Noor, Juliansyah. 2017. Metodologi Penelitian : Skripsi, Tesis, Disertasi \& Karya Ilmiah. Jakarta : Kencana.

Straffin, Philip. 1993. Game Theory and Strategy. Vol. 36. USA : MMA.

Subagyo, Pangestu. 2009. Dasar-Dasar Operation Research. Edisi 2. Yogyakarta : BPFE.

Tobing, Tri Paulina Lumban. 2018. Skripsi : Strategi Kompetisi Antar Gojek dan Grab dengan Menggunakan Game Theory. Universitas Sumatera Utara : Departemen Matematika FMIPA. 